\title{
Nursing consultation tool for people with human immunodeficiency virus/tuberculosis co-infection
}

\author{
Instrumento de consulta de enfermagem para pessoas com coinfecção pelo vírus da \\ imunodeficiência humana/tuberculose
}

\author{
Herramienta de consulta de enfermería para personas con coinfección por el virus de \\ inmunodeficiencia humana/tuberculosis
}

Alexsandra Rodrigues Feijão ${ }^{1}$, Gilmara Holanda da Cunha², Joselany Áfio Caetano², Elucir Gir ${ }^{3}$, Marli Teresinha Gimeniz Galvão

Objective: to verify the opinion of judges about a nursing consultation tool for people with co-infection by the human immunodeficiency virus and tuberculosis. Methods: methodological study, involving the construction of a tool based on Orem's self-care theory and its submission for evaluation by judges experts in the area, which gave opinions about organization, clarity and relevance. Results: the instrument gained a positive evaluation for all assessment criteria, with agreement greater than $75.0 \%$ and Content Validity Index greater than 0.80 in most items. Following judges opinion, three items were excluded and two modified. Conclusion: the adequacy of the nursing consultation tool for people with HIV/ tuberculosis co-infection was confirmed regarding organization into subdivisions and items. Minimal disagreement among judges in the analysis of the issues was noted. Although most items were evaluated positively, further validation studies will be needed.

Descriptors: HIV; Acquired Immunodeficiency Syndrome; Tuberculosis; Nursing Care.

Objetivo: verificar a opinião de juízes acerca de instrumento para consulta de enfermagem a pessoas com coinfecção pelo vírus da imunodeficiência humana e tuberculose. Métodos: estudo metodológico, envolvendo a construção de instrumento baseado na teoria do autocuidado de Orem, e a submissão deste à avaliação de juízes experts na área, os quais emitiram pareceres acerca da organização, clareza e relevância. Resultados: o instrumento obteve avaliação positiva quanto a todos os critérios de avaliação, com concordância maior que 75,0\% e Índice de Validade de Conteúdo superior a 0,80 na maioria dos itens. Conforme parecer dos juízes, três itens foram excluídos e dois modificados. Conclusão: verificou-se a adequação do instrumento consulta de enfermagem para pessoas com coinfecção HIV/tuberculose, quanto à organização em subdivisões e itens. Segundo percebeu-se, houve reduzida discordância entre os juízes na análise das questões. Apesar maioria dos itens ter sido avaliada positivamente, serão necessários outros estudos de validação.

Descritores: HIV; Síndrome de Imunodeficiência Adquirida; Tuberculose; Cuidados de Enfermagem.

Objetivo: verificar opiniones de jueces acerca de instrumento para consulta de enfermería a personas con coinfección por el virus de la inmunodeficiencia humana y tuberculosis. Métodos: estudio metodológico, involucrando la construcción de instrumento basado en la teoría del autocuidado de Orem, y sumisión de esto a evaluación de expertos jueces en el área, que evaluaron organización, claridad y relevancia. Resultados: el instrumento obtuvo evaluación positiva para los criterios de evaluación, con concordancia mayor que 75,0\% e Índice de Validez el Contenido mayor que 0,80 en la mayoría de los ítems. Según pareceres, tres artículos fueron excluidos y dos modificados. Conclusión: hubo adecuación de la herramienta de consulta de enfermería para personas con coinfección VIH/tuberculosis cuanto a la organización en subdivisiones e ítems. Se percibió reducido desacuerdo entre jueces en el análisis de las cuestiones. La mayoría de los ítems fueron evaluados positivamente, pero otros estudios de validación son necesarios.

Descriptores: VHI; Síndrome de Inmunodeficiencia Adquirida; Tuberculosis; Atención de Enfermería.

\footnotetext{
${ }^{1}$ Universidade Federal do Rio Grande do Norte. Natal, RN, Brazil.

${ }^{2}$ Universidade Federal do Ceará. Fortaleza, CE, Brazil.

${ }^{3}$ Escola de Enfermagem de Ribeirão Preto, Universidade de São Paulo. Ribeirão Preto, SP, Brazil.

Corresponding author: Gilmara Holanda da Cunha

Rua Alexandre Baraúna, 1115, Rodolfo Teófilo. CEP: 60430-160. Fortaleza, CE, Brazil. E-mail: gilmaraholandaufc@yahoo.com.br
} 


\section{Introduction}

Tuberculosis is responsible for high rates of mortality among people living with human immunodeficiency virus nowadays. In co-infection, these diseases have a synergistic effect, increase the deterioration of immunity and can result in premature death if not treated appropriately. In addition, both infections are concentrated in poor areas, where resources for diagnosis, treatment and control are scarce, requiring coordination of actions undertaken by the respective programs in order to improve the support provided ${ }^{(1-2)}$.

In countries with endemic tuberculosis, the incidence of epidemic human immunodeficiency virus/acquired immunodeficiency syndrome (HIV/ AIDS) has increased cases of pulmonary tuberculosis with smear-negative and extrapulmonary forms. Although these forms of the disease are less infectious compared to smear positive tuberculosis, patients are more immunocompromised, present more adverse reactions to drugs and have higher mortality rates, what is aggravated by late diagnosis of these forms ${ }^{(2)}$.

In 2013, 1.1 million people (13.0\%) out of the nine million who developed tuberculosis in the world were HIV-positive. Brazil, one of the 41 countries with the highest HIV/tuberculosis co-infection rates, notified about 54,000 cases of tuberculosis with known serology for HIV in 2013. It is noteworthy that in the world, the incidence and morbidity-mortality by co-infection decreased in recent years with advancing early detection and actions to prevent and reduce damage. However, in Brazil these remained stable between 2002 and $2013^{(3)}$.

In this perspective, the HIV/tuberculosis co-infection figures as a serious problem of public health, and represents a challenge because AIDS lacks a treatment leading to cure, besides the social and economic barriers that interfere with adherence to treatment regimen of co-infection. Thus, the recommendations of the World Health Organization aiming at prevention of deaths by tuberculosis among people living with HIV involve intensification of preventive actions against tuberculosis, as well as diagnostic intervention and earlier treatment and onset of antiretroviral therapy among people living with HIV and people with HIV-associated tuberculosis. Such actions require collective and collaborative knowledge ${ }^{(3)}$.

Nursing is inserted in this context of global efforts because it performs interventions for people living with HIV/AIDS (PLWHA) and tuberculosis in different levels of health care. The realization of these activities are based in the nursing process consisting of history, diagnosis, planning, implementation and evaluation, promoting individualized and appropriate care for each patient, and allowing the use of theories for its implementation ${ }^{(4)}$.

Nursing consultation of people with HIV/ tuberculosis co-infection followed in specialized clinics must contemplate aspects of the health-disease process, encourage self-care, implement preventive actions, search for contacts and invest in treatment compliance. However, instruments to guide the nursing consultation and to standardize the care given to these patients are scarce.

Given the above, it is essential to improve the assistance toward HIV/tuberculosis co-infected patients, due to the fact that they have the highest rates of treatment failure and recurrence of tuberculosis and therefore they require more assistance for their self-care in this context ${ }^{(2)}$.

Thus, in order to contribute to nursing care for PLWHA, this study proposed to develop and verify the clarity and relevance of a tool to be used in nursing consultation to HIV/tuberculosis co-infected adults, 
through opinion judges. Orem's theory of self-care was adopted as theoretical framework.

Considering that the general theory of Dorothea Orem consists of self-care theory, self-care deficit theory and the theory of nursing systems ${ }^{(5)}$, the selfcare theory was the one chosen to build the nursing consultation tool for HIV/tuberculosis co-infected people. This theory has already been used in other studies including the Systematization of Nursing Care for patients with HIV/AIDS ${ }^{(6-7)}$.

\section{Method}

This was a methodological development study carried out in 2010. Initially, we built a nursing consultation tool directed to people with coinfection HIV-Tuberculosis with posterior evaluation of clarity and relevance of its content by judges.

Literature review of the theme was performed prior to construction of the tool. Search took place using the DeCS (Health Sciences Descriptors) uncontrolled Nursing care, HIV infections, HIV and Tuberculosis in the SciELO (Scientific Electronic Library Online) and LILACS (Latin America and the Caribbean Literature) databases. As criteria for inclusion, articles were selected when available in full-length for free and when addressing nursing care toward patients with HIV/tuberculosis co-infection. Fifteen articles were found in this search and after reading titles and abstracts for application of criteria for inclusion, a total of six studies were selected, being thereby read in its entirety. These articles contributed to preparation of items of the consultation tool.

In addition to the results of this review and in order to comply with the tool archetypal, the nursing process outlined by Orem in the Self-Care Theory was used. This consists of three steps: a) determine why the patient needs care (research and nursing diagnosis); b) designate a nursing care system and plan of care (planning and implementing interventions); c) Manage the designated nursing system (control and evaluation).

These phases constitute the framework of the consultation systematization. In this study, selfcare requirements of Orem's referential (universal, developmental and health deviation) are present in the tool, guiding questions, remarks in nursing history and follow-up visits. Finally, the tool was designed with 67 items in four parts: Identification (10 items), clinical data (7 items), history/1st consultation (40 items), subsequent consultations (10 items).

In the sequence, the tool was submitted to judges' appreciation. As criteria for choosing judges, were included: Ph.D. in nursing, developing studies related to nursing care for people with HIV/AIDS and tuberculosis. After applying these criteria in the filters of the Lattes Platform of the National Council of Scientific and Technological Development, 29 resumes were obtained and, after analysis, the initial sample was composed of 16 judges. All were invited to participate via e-mail containing an informed consent, the invitation, an evaluation instrument and the nursing consultation model. After the deadline for return, only five judges returned the instrument fully evaluated, and these five participants composed the sample.

Considering that validation decides whether the tool measures in fact what it purports to measure, an evaluation instrument for judges' appreciation, made up of the consultation model items and of the following parameters ${ }^{(8)}$ : organization, clarity and comprehension of content.

Regarding organization, judges observed over the tool construct relating to the identification, clinical data, history and nursing consultations. Then, each part of the tool was analyzed for clarity and 
comprehension of content seeking the intelligibility of each item of the consultation composition.

Each of the 67 items of the tool was evaluated in relation to established criteria for which judges should answer yes or no; furthermore, they would inform the degree of relevance of each item displayed using a Likert scale: irrelevant, little relevant, relevant and very relevant. Open space for comments and/ or suggestions was available in the evaluation instrument.

Items with equal proportion of answers among judges over $75.0 \%$ were considered for analysis of responses. Items with percentage lower than the stipulated were deleted or changed according to the suggestions of judges. Furthermore, items considered irrelevant or little relevant by two or more evaluators were excluded in the phase of evaluating of relevance of the model.

Data were first organized and analyzed through evaluation of percentage of agreement between judges. The Content Validity Index was adopted to analyze the correlation between the responses of evaluators. All Content Validity Indices were calculated separately (number of items evaluated as equivalent to two judges) divided by the total of items ${ }^{(9)}$ and summed to compute the overall Content Validity Index of the tool. The minimum ratio of 0.75 was established for evaluation of each item and for evaluation of the tool in general.

The project was submitted to the Ethics Committee of São José Hospital, also in accordance with Resolution № 196/96 of the National Health Council and was approved by Protocol № 035/2009. All individuals signed a free and informed consent form.

\section{Results}

Regarding the characterization of judges, all were female, mean age of 40.8 years, average work time in the area of 8.2 years and average time of expertise $(\mathrm{PhD})$ of 6.3 years. All were affiliated to public universities, four in the Northeast and one in the Southeast.

Evaluators analyzed the 67 items of the tool containing the nursing consultation model. Table 1 shows the distribution of evaluation of each judge on the criteria clarity and comprehension of the parts of the nursing consultation model and its items, with dichotomous answer Yes or No. The consultation tool received a positive evaluation because there was agreement in more than $70.0 \%$, reflecting to be clear and easy to understand.

It is noteworthy that the percentage of agreement was also analyzed in each item of the tool, even considering suggestions of the evaluators. The item schooling level in the subdivision 'identification' obtained a percent agreement of $20.0 \%$ for clarity and comprehension because it was presented in years of formal schooling, suggesting the use of educational ranges. Another item with low percentage of agreement (40.0\%) was the provenience, which has been modified to municipality of residence. Regarding clinical data, collection of date was suggested to be added in the item requested exams where there is research for resistant acid-fast bacilli.

Regarding the level of relevance of the tool items (Table 2), all evaluators' answers were considered for all items concerning the criteria irrelevant, little relevant, relevant and very relevant. Note that the highest percentage of responses is the relevant level (57.9\%), followed by very significant (38.5\%). 
Table 1 - Distribution of judges regarding clarity and comprehension of each part of the nursing consultation tool

\begin{tabular}{|c|c|c|c|c|c|}
\hline \multirow{2}{*}{$\begin{array}{l}\text { Nursing consultation (clarity and } \\
\text { comprehension criteria) }\end{array}$} & Judge1 & Judge2 & Judge3 & Judge4 & Judge5 \\
\hline & n(\%) & n(\%) & n(\%) & $n(\%)$ & $n(\%)$ \\
\hline \multicolumn{6}{|l|}{ Identification (10 items) } \\
\hline Yes & $7(70.0)$ & $9(90.0)$ & $9(90.0)$ & $8(80.0)$ & $9(90.0)$ \\
\hline No & $3(30.0)$ & $1(10.0)$ & $1(10.0)$ & $2(20.0)$ & $1(10.0)$ \\
\hline \multicolumn{6}{|l|}{ Clinical data (7 items) } \\
\hline Yes & $5(71.0)$ & $6(85.7)$ & $7(100.0)$ & $6(85.7)$ & $6(85.7)$ \\
\hline No & $2(29.0)$ & $1(14.3)$ & -- & $1(14.3)$ & $1(14.3)$ \\
\hline \multicolumn{6}{|l|}{ History/1st consultation (40 items) } \\
\hline Yes & $38(95.0)$ & $37(92.5)$ & $40(100.0)$ & $38(95.0)$ & $40(100.0)$ \\
\hline No & $2(4.0)$ & $3(6.5)$ & -- & $2(4.0)$ & $0(0.0)$ \\
\hline \multicolumn{6}{|l|}{ Subsequent consultations (10 items) } \\
\hline Yes & $9(90.0)$ & $10(100.0)$ & $10(100.0)$ & $10(100.0)$ & $9(90.0)$ \\
\hline No & $1(10.0)$ & -- & -- & -- & $1(10.0)$ \\
\hline
\end{tabular}

Table 2 - Distribution of judges regarding relevance of the items of the nursing consultation tool

\begin{tabular}{lc}
\hline Evaluation & n (\%) \\
\hline Irrelevant & $6(1.8)$ \\
Little relevant & $4(1.2)$ \\
Relevant & $194(57.9)$ \\
Very relevant & $131(39.1)$ \\
Total & $335(100.0)$ \\
\hline
\end{tabular}

Table 3 shows the results of judges' evaluation and the Content Validity Index for all items regarding the criteria evaluated. Most of the items presented index above 0.80 , which denotes a positive evaluation when considering the cutoff point of 0.75 . The items "access to other health services", "body mass index" and "formal physical exercise" were considered irrelevant by two judges and were excluded from the tool. The items "leisure activities" and "social participation" were classified as unimportant by a judge, but were not excluded for lack of agreement and failure to provide justification for exclusion. There was a suggestion of addition in the item use of condoms during sexual intercourse of alternatives always and sometimes, in the case of positive response.

After evaluation and consideration of all aspects suggested by judges, the tool was adapted with modification and exclusion of items. Finally, the nursing consultation tool had 64 items, with only two items altered. 
Table 3 - Judges' evaluation of items of the nursing consultation tool for people with HIV/tuberculosis coinfection

\begin{tabular}{|c|c|c|c|c|c|}
\hline \multirow{3}{*}{ Subdivisions and items of the tool } & \multicolumn{4}{|c|}{ Opinions of judges } & \multirow{3}{*}{ CVI } \\
\hline & I & LR & $\mathbf{R}$ & VR & \\
\hline & n(\%) & n(\%) & n(\%) & n(\%) & \\
\hline \multicolumn{6}{|l|}{ Identification } \\
\hline Current age & 0 & 0 & $4(80.0)$ & $1(20.0)$ & 0.80 \\
\hline Marital status & 0 & 0 & 0 & $5(100.0)$ & 1.00 \\
\hline Partner serology & 0 & 0 & 0 & $5(100.0)$ & 1.00 \\
\hline Number of children & 0 & 0 & $4(80.0)$ & $1(20.0)$ & 0.80 \\
\hline Education & 0 & 0 & $5(100.0)$ & 0 & 1.00 \\
\hline Occupation & 0 & 0 & $5(100.0)$ & 0 & 1.00 \\
\hline Monthly family income & 0 & 0 & 0 & $5(100.0)$ & 1.00 \\
\hline Provenience & 0 & $1(20.0)$ & $4(80.0)$ & 0 & 0.80 \\
\hline Access to other health services & $2(40.0)$ & $1(20.0)$ & $2(40.0)$ & 0 & 0.45 \\
\hline Difficulties in accessing service & 0 & 0 & 0 & $5(100.0)$ & 1.00 \\
\hline \multicolumn{6}{|l|}{ Clinical data } \\
\hline Year of diagnosis of HIV infection & 0 & 0 & $1(20.0)$ & $4(80.0)$ & 0.80 \\
\hline Exposure Category & 0 & 0 & $5(100.0)$ & 0 & 1.00 \\
\hline Time of diagnosis of tuberculosis (in months) & 0 & 0 & 0 & $5(100.0)$ & 1.00 \\
\hline Tuberculosis characterization (3 items) & 0 & 0 & 0 & $5(100.0)$ & 1.00 \\
\hline Exams performed & 0 & 0 & 0 & $5(100.0)$ & 1.00 \\
\hline \multicolumn{6}{|l|}{ History of nursing / 1st consultation } \\
\hline Aspects related to medication ( 2 items) & 0 & 0 & 0 & $5(100.0)$ & 1.00 \\
\hline Vital signs and weight & 0 & 0 & 0 & $5(100.0)$ & 1.00 \\
\hline Body Mass Index & $2(40.0)$ & 0 & $3(60.0)$ & 0 & 0.65 \\
\hline \multicolumn{6}{|l|}{ Universal requirements of self-care } \\
\hline Hydration and nutrition (3 items) & 0 & 0 & 0 & $5(100.0)$ & 1.00 \\
\hline Respiration, elimination and excretion (9 items) & 0 & 0 & 0 & $5(100.0)$ & 1.00 \\
\hline Balance between activity and rest ( 3 items) & 0 & 0 & 0 & $5(100.0)$ & 1.00 \\
\hline Formal physical exercise & $2(40.0)$ & 0 & $3(60.0)$ & 0 & 0.65 \\
\hline Leisure activities & 0 & $1(20.0)$ & $4(80.0)$ & 0 & 0.80 \\
\hline Who do you live with & 0 & 0 & 0 & $5(100.0)$ & 1.00 \\
\hline Social participation & 0 & $1(20.0)$ & $4(80.0)$ & 0 & 0.80 \\
\hline Prevention of risks to life and well-being ( 3 items) & 0 & 0 & 0 & $5(100.0)$ & 1.00 \\
\hline Developmental self-care requirements (3 items) & 0 & 0 & 0 & $5(100.0)$ & 1.00 \\
\hline Self-care requirements for health deviation (5 items) & 0 & 0 & $1(20.0)$ & $4(80.0)$ & 0.80 \\
\hline Identified antibody deficits & 0 & 0 & 0 & $5(100.0)$ & 1.00 \\
\hline Nursing diagnoses & 0 & 0 & 0 & $5(100.0)$ & 1.00 \\
\hline Nursing prescriptions & 0 & 0 & 0 & $5(100.0)$ & 1.00 \\
\hline \multicolumn{6}{|l|}{ Subsequent consultations } \\
\hline Attended consultation & 0 & 0 & 0 & $5(100.0)$ & 1.00 \\
\hline Conducted active search & 0 & 0 & $1(20.0)$ & $4(80.0)$ & 0.80 \\
\hline Remains in treatment - Scheme & 0 & 0 & 0 & $5(100.0)$ & 1.00 \\
\hline Re-schedule of consultation for & 0 & 0 & $1(20.0)$ & $4(80.0)$ & 0.80 \\
\hline If did not remain in treatment, foreclosure situation & 0 & 0 & 0 & $5(100.0)$ & 1.00 \\
\hline Nursing process (4 items) & 0 & 0 & 0 & $5(100.0)$ & 1.00 \\
\hline Other observations/occurrences & 0 & 0 & $1(20.0)$ & $4(80.0)$ & 0.80 \\
\hline
\end{tabular}




\section{Discussion}

Systematization, organization, specific instruments and scientific basis are necessary in order to safely practice nursing ${ }^{(10)}$. These practice requirements may find basis in nursing theories. According to the present findings, Orem's General Self-care Theory was adequate for outpatient context of HIV/tuberculosis co-infected patients.

Overall, the evaluation by judges identified the suitability of the instrument, nursing consultation for people with HIV/tuberculosis co-infection, regarding organization into subdivisions and items. As noted, little disagreement occurred between judges in the analysis of the issues. Most of the items were positively evaluated, considering the Content Validity Index above 0.8 . This value complies with criteria for validation of this tool. Thus, the items were considered consistent with respect to the cited evaluation criteria.

Thus, clarity and comprehension are inherent to the proposed consultation model and this represents an aspect of practical value for its application. Such features provide better reliability of information, as the percentage of agreement among evaluators was above $75 \%$. Therefore, it is imperative that all communication be done in a clear, transparent and complete manner, because otherwise the communication with the patient and other team members may be interrupted and will make the tool fail to achieve its purpose $\mathrm{e}^{(11-16)}$.

The evaluation of judges concerning level of relevance revealed the importance of each item for patient care. Regarding this criterion, there was a positive evaluation by judges with high agreement among them. More than half of the items were classified as relevant and only $1.8 \%$ were considered irrelevant. Notably, items considered irrelevant, even when they reached the lower index of $70 \%$, were excluded. However, items with little relevant assessment were subjected to the criterion of minimum agreement for exclusion.
Nursing consultation implies direct contact with the individual and directs the actions of nurses, and thus needs to have scientific basis ${ }^{(4)}$. Hence, the forms used in consultations must be organized under the light of clinical reasoning in order to facilitate the systematization of care ${ }^{(10)}$. It is noteworthy that the area devoted to consultations of follow-up of cases visits was drawn up with descriptive items such as identified self-care deficits, nursing diagnostics and interventions, patient evolution. So, consultation under the precepts of systematization of nursing care was inserted. In this, different possibilities are considered by clinical reasoning, avoiding hasty conclusions about the patient's needs ${ }^{(16)}$.

National guidelines for the treatment of HIV/tuberculosis co-infection advocate the same recommendations of basic outline for uninfected. One should call the contacts and provide the option to perform the Directly Observed Treatment in the nearest basic health unit ${ }^{(2)}$. This aspect was considered during the preparation of the consultation model proposed by this study and was positively evaluated by judges in evaluating all the criteria.

\section{Conclusion}

Given the results, we conclude that the nursing consultation model based on Orem's Theory for people living with HIV/tuberculosis co-infection was validated in its contents, as the evaluation by judges resulted in a general Content Validity Index of the items above 0.8 , percentage of agreement above $70 \%$ for the clarity and comprehension, and $96.4 \%$ of items were considered relevant to very relevant tin the evaluation of relevance.

In face of the application of theoretical referential through the nursing care methodology, consisting of this tool, it is worth noting that this study is focused on assistance. However, because only the verification of judges' opinion regarding the tool it was carried out, but not clinical validation, the use of 
this service in daily practice can give rise to new needs for adaptation, which will require further studies of validity.

With respect to limitations of the study, reduced sample size figures as one limitation and culminated preventing the use of other forms of data analysis such as Kappa as well as reduced the reliability of validation. Another important limitation was the inability to use the Delphi technique, which would increase the accuracy of the instrument rating, due to the termination deadlines of the study.

\section{Collaborations}

Feijão AR, Galvão MTG and Cunha GH contributed to the design of the work, data collection, analysis and interpretation of data and writing of the article. Caetano JA and Gir E contributed to analysis and interpretation of data and writing of the article.

\section{References}

1. Gao L, Zhou F, Li X, Jin Q. HIV/TB co-infection in mailand China: a meta-analysis. PLos One. 2010; 5(5):1-6.

2. Ministério da Saúde (BR). Manual de recomendações para o controle da tuberculose no Brasil, Secretaria de Vigilância em Saúde. Departamento de Vigilância Epidemiológica. Brasília: Ministério da Saúde; 2011.

3. World Health Organization. WHO Global tuberculosis report 2014. WHO Library Cataloguing-in-Publication Data. [Internet] 2014 [cited 2015 July 13]. Available from: http://www. who.int/tb/publications/global_report/en/

4. Crozeta K, Stocco JGD, Labronici LM, Meier MJ. Interface between ethics and technological nursing concepts. Acta Paul Enferm. 2010; 23(2):239-43.
5. George JB. Teorias de enfermagem: os fundamentos à prática profissional. Porto Alegre: Artes Médicas Sul; 2000.

6. Silva MR, Bettencourt ARC, Diccini S, Belasco A, Barbosa DA. Diagnósticos de enfermagem em portadores da Síndrome da Imunodeficiência Adquirida. Rev Bras Enferm. 2009; 62(1):92-9.

7. Cunha GH, Galvão MTG. Nursing diagnoses in patients with Human Immunodeficiency Virus/Acquired Immunodeficiency Syndrome in outpatient care. Acta Paul Enferm. 2010; 23(4):526-32.

8. Hill MM, Hill A. Investigação por questionário. Lisboa: Edições Silabo; 2005.

9. Waltz CF, Strickland O, Lenz E. Measurement in nursing and health research. 4. ed. New York: Springer Publishing Company; 2010.

10. Curcio R, Lima MHM, Torres HC. Protocolo para consulta de enfermagem: assistência a pacientes com diabetes melittus tipo 2 em insulinoterapia. Rev Gaúcha Enferm. 2009; 30(3):552-7.

11. Galvão MTG, Cunha GH, Rodrigues NLC, Gir E. Aspects of social interactions of HIV-positive children from the perspective of their caregivers. Rev Rene. 2013; 14(1):262-71.

12. Galvão MTG, Cunha GH, Machado MMT. Dilemas e conflitos de ser mãe na vigência do HIV/AIDS. Rev Bras Enferm. 2010; 63(3):371-6.

13. Duarte PS, Ramos DG, Pereira JCR. Padrão de incorporação de fármacos antirretrovirais pelo sistema público de saúde no Brasil. Rev Bras Epidemiol. 2011; 14(4):541-7.

14. Guerra CPP, Seidl EMF. Adherence in HIV/AIDS: a study with adolescents and their primary caregivers. Psicol Estud. 2010; 15(4):781-789.

15. Souza SS, Silva DMGV. Passando pela experiência do tratamento para tuberculose. Texto Contexto Enferm. 2010; 19(4):636-43.

16. Maksud I. Silêncios e segredos: aspectos (não falados) da conjugalidade face à sorodiscordância para o HIV/AIDS. Cad Saúde Pública. 2012; 28(6):1196-204. 